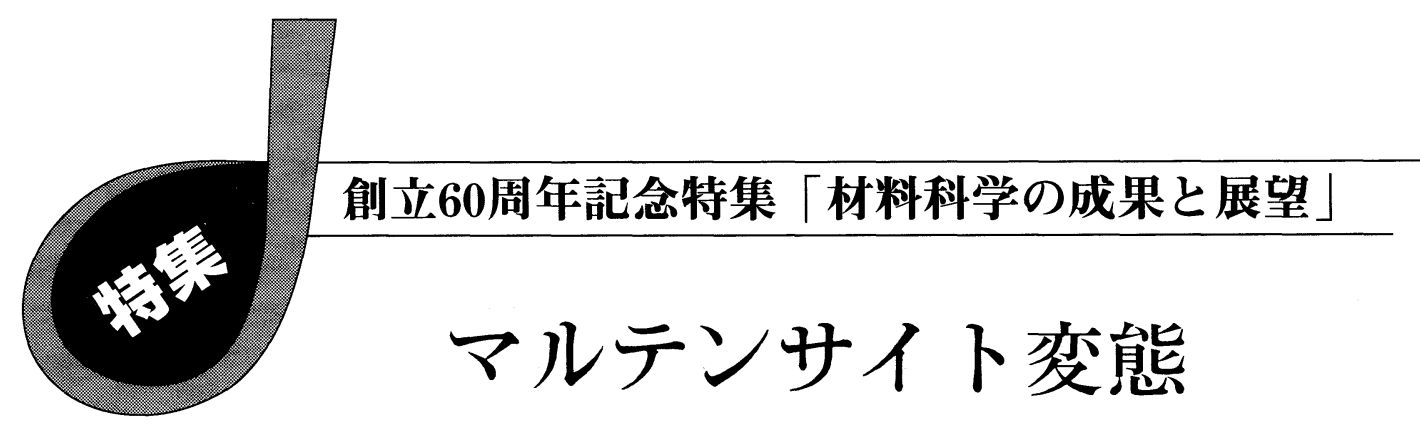

大䒯 和 弘*

マルテンサイト変態(以下 $\mathrm{M}$ 変態と略記) は言ら迄もな く, 固相に持ける典型的な協力現象で, 一つ一つの原子の変 位は小さいが，ある領域の原子が同一の変位をするため(こ れ故 $\mathrm{M}$ 変態は military transformation または将棋倒し式変 態とも呼ばれる), 形状記憶効果や超弾性のような特異な性 質を示し, 新機能材料開発といら観点からも関心を持たれて いる相変態である. 特に日本では, 西山-清水の伝統があり, これ迄活発な研究が行われてきた. 前回の50周年の特集号 では清水 ${ }^{(1)}$ がそれ迄の総括を行っているので，ここではその 後の10年間を対象とする.ただ M 変態と一口に言ってもは なはだ多岐に亘っていて，そのすべてに精通することは困難 であり, 紙数も限られているので独断と偏見を免れないと思 らが，その点読者の御海容を御願いしたい。以下対象を 8 項目に絞って, その成果と期待される発展を紹介する.なお 紙数の都合で, 引用文献は一部に限らざるをえず, 網羅的に はなっていないことを御断りして特く。

\section{1. マルテンサイトの核形成と変態前駆現象}

Fisher 等に端を発する $\mathrm{M}$ 変態の核形成に関する classical theoryは, 古いが基本的な問題である. この古典論を $\mathrm{Fe}$ 系 の $\mathrm{M}$ 変態に適用すると, 活性化ェネルギーが $10^{4} \mathrm{eV}$ とい とてつもなく大きな值が得られるが, 現実には $\mathrm{M}$ 変態は起 きている. この矛盾をどうするかといらのが基本的な問題で ある. この矛盾を解消するためこれ迄種々な考えが提唱され てきた. classical theoryでは, 核はバルクの $\mathrm{M}$ と同じ構造 を持つと仮定されているが，核形成の過程では必ずしも最終 構造を取る必要はなく，ェネルギーの低い non-classical pathを取るといら考光方もあり，Olson-Cohen 理論のよう に, 特別な配列をした母相中の格子欠陥が $\mathrm{M}$ の核になると いら説, 欠陥の周りの応力場が核形成を助けるといった説, lattice softening のように格子振動の役割を重視した考方, tweedのような前駆現象の存在によって $\mathrm{M}$ 変態が可能にな るという考方方など，理論的実験的に種々な考えが展開され てきたが，まだ一般的に広く受け入れられた考方方はない. ひと頃誘電体に拈けるソフトモードとのからみで，ソフトモ ードに関心が集まったこともあるが，1次の相変態である $\mathrm{M}$ 変態にソフトモードは存在しない(フォノンのエネルギーが ゼロになるといら簃密な意味でのソフトモード). また In$\mathrm{Ti}^{(2)}$ や $\mathrm{Na}^{(3)}$ では, $M s$ 点 $(\mathrm{M}$ 変態開始温度) 直上でもフォノ ンのソフト化は起きていないことが確認されている。すなわ ち, フォノンのソフト化は必ずしも $\mathrm{M}$ 変態にとって必要条 件ではないといら共通認識はできたと思われる. 一方 $\mathrm{M}$ 変 態の一つの大きな特徵は, 変態の際の変態歪の発生にある. このため, $\mathrm{Fe}$ 系 $\mathrm{M}$ 変態のように変態丕の大きな変態は強い $\mathrm{M}$ 変態, 雨の小さい変態は弱い $\mathrm{M}$ 変態と呼ばれることがあ る. 強い $\mathrm{M}$ 変態では, 大きな歪効果のために, 格子振動の 効果が見えないのに対し，弱い $\mathrm{M}$ 変態ではこれらが見える 可能性がある. 実際, Ni-A1の B2-14M(7R)変態(4), Au-Cd の $\mathrm{B} 2-\zeta_{2}^{\prime}$ (trigonal) 変態 ${ }^{(5)}$, Ti-Ni-Fe の B2-R 相変態 ${ }^{(6)}$ では, 構造変化に対応する明確なフォノンのソフト化が観察されて 扣り, tweed ${ }^{(7)}$ のよな前駆現象も含めて，このような方向 からの研究が重要になってくると思われる.ただ, tweedが $\mathrm{M}$ 変態にとって不可欠な前駆現象であるか否かについては, 議論のあるところである。ぬたこれらの問題とからんで, Ti-Ni-Fe の R 相変態に拈いては, B2-incommesurate(IC)commensurate $(\mathrm{R}$ 相) といら順序で変態が起こるというのが これ迄の定説 ${ }^{(8)}$ であったが, 最近の電顕による動的観察で は $^{(9)}$, 変態の際 $\mathrm{B} 2$ 相と $\mathrm{R}$ 相は共存していて, IC 相は存在 しないといら結果が得られて牤り, 金属の $\mathrm{M}$ 変態に括ける incommensurability の問題は重要になってくると思われる.

* 筑波大学教授 ; 物質工学系 (元305 つくば市天王台1-1-1)

Martensitic Transformations; Kazuhiro Otsuka(Institute of Materials Science, University of Tsukuba, Tsukuba)

Keywords: martensitic transformations, crystallography, thermodynamics, kinetics, ageing effect, rubber-like behavior, thin films, intelligent materials, computer simulation, bainitie transformation

1997年 5 月 8 日受理 


\section{2. マルテンサイト変態の結晶学と第I種双晶}

$「 \mathrm{M}$ 変態の現象論」との矛盾でそれ迄問題となっていた $\mathrm{Cu}-\mathrm{Al}-\mathrm{Ni}$ 合金の $\beta_{1}\left(\mathrm{DO}_{3}\right)-\gamma_{1}^{\prime}$ (orthorhombic) 変態も，格子不 変変形として第種双晶 $\left(K_{1}\right.$ 面 : irrational) を導入すること により解決したことは, 前回の展望でる紹介された ${ }^{(1)}$ 。その 後多くの合金系に対し，「現象論」と実験結果との critical な比較が行われたが，その結果，格子不変変形を正しく選べ ば，殆どの合金系に対し「現象論」が良く成り立つことが示 された ${ }^{(10)}$. その中で特に問題だったのは $\mathrm{Au}-\mathrm{Cd}$ 合金に括け る B2- $\zeta_{2}^{\prime}$ (trigonal) 変態である. この系では, 格子不変変形 があるとする説 ${ }^{(11)}$ と格子不変変形はないとする説 ${ }^{(12)}$ が対立 していたが，その後の詳細な研究により，この系では変態昰 が非常に小さいため, 両方の変態過程のありらることが理論 的実験的に示されて解決した ${ }^{(13)}$. ところで上述した，irra-

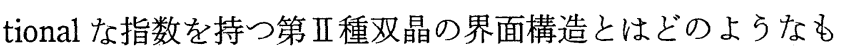
のであろらか？ Knowlesら ${ }^{(14)}$ は, rational な指数を持つ ledge と stepからなり，その平均が irrational になる界面を 提唱している。しかし実験的には, uniqueな $\eta_{1}$ 軸 $\left(\eta_{1}:\right.$ rational な双晶シアー方向)方向から高分解能電顕で観察して む ledge や step は観察されず，むしろ本質的に irrational な 界面と考光る方が妥当であると思われる(15)(16). すなわち， 界面がシャープな, 第 I 種双晶とは異なって, 界面はある幅 を持って㧊り, この中で弾性的に需みながら, 双晶方位へと 変化して和り，これをサポートする解析子ある.

$\mathrm{M}$ 変態の結晶学のもら一つの側面としては， M の精密構 造解析がある. 上く知られているょらに, M 変態に際して は多数の variants が生成するので, 単結晶の母相を用いて も, M の単結晶を得ることは困難であるが, 応力誘起変態 の手法を用いて $\mathrm{M}$ 単結晶を得ることが可能になり, Ti-

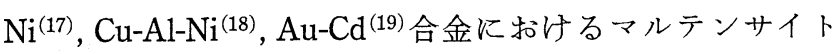
の精密構造解析が行われた, 先に述べた「M変態の現象論」 そ沶いて問題になるのは变態歪であるので, 必要なのは格子 定数だけであり, シャッフルも含めた原子の精密な位置は必 要ではない。しかし $\mathrm{M}$ 相のバンド構造を計算するとなる と,すべての原子の精密な位置が必要になる.すなわち, 上 述した精密構造解析はこのための準備のできたことを示する のであり，M 相のバンド計算も既飞始まっている(20). 電子 論に立脚した $\mathrm{M}$ 変態の研究は, これからの発展が大いに期 待される領域である.

\section{3. マルテンサイト変態の熱力学とカイネティクス}

これ迄 $\mathrm{M}$ 変態は一般に athermal(非等温)変態で, 時間依 存性を持たず, 長時間保持しても $M s$ 点以上では変態は起こ らないと考学られてきた．一方で Fe-Ni-Mnなど一部の合金 でしか見出されていなかったが，冷却漈して $M s$ 点をもた ず, $\mathrm{C}$ 曲線のノーズ温度と呼ばれる適当な温度に長時間保持
すると，ある潜伏期間の後，変態の起こる isothermal(等温) 変態と呼ばれる $\mathrm{M}$ 変態もあり, 両者は機構的にも全く異な るものと考兄られてきた。しかし掛下らは，磁場を印加する ことによって等温変態も非等温変態に変り, また静水圧を印 加することによって非等温変態も等温変態に変化することを 示し，等温変態と非等温変態を統一的に扱ら統計熱力学モデ ルを提唱した ${ }^{(21)}$. その骨子を簡単に述べれば以下のように なる.変態に必要な駆動力 $\delta$ は決まっているとする. 次に 母相と $\mathrm{M}$ 相の自由エネルギー差を $\Delta G$ とし， $\Delta=\delta-\Delta G$ を ギャップ・エネルギーと定義する. 試料を冷却していった時, $\Delta=0$ となれば, その温度で変態は開始し, その温度が $M s$ 点を与光ることになる. $0 \mathrm{~K}$ まで泠却しても， $\Delta=0$ となら ない時は $\mathrm{M}$ 変態は起こらないことになるが，もし磁場など によって ののェネルギーを外部から与光れば，上述した磁

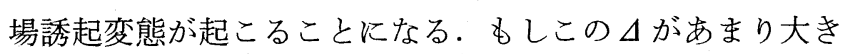
くなくて, 熱摇動でこのエネルギーの山を越光れば等温変態 が生ずるといらことになる．この際 $\mathrm{M}$ 相の核ができるため には，ある大きさの領域の原子が熱活性化されなければなら ず，その確率が $\Delta$ を含む，ボルッマン因子で与兄られると 考光, その逆数が潜伏期間を与兄ると考光る。いくつかの adjustable parameters を含むが, C曲線の形や, 等温変態 $\Leftrightarrow$ 非等温変態の遷移を説明することができた。 またこのモ デル飞従えば, $M s$ 点以上で等温変態の起こることが期待さ れるが，実際 $\mathrm{Na}^{(3)}, \mathrm{In}-\mathrm{Tl}^{(22)}, \mathrm{Fe}-\mathrm{Ni}^{(23)}$ などでこの種の等温 変態が見出されている. これ迄 $\mathrm{M}$ 変態では, 結晶学的研究 に比べ, 熱力学的研究は遅れていただけに, このような新し い観点泣つ, $\mathrm{M}$ 変態の熱力学やカイネティックスの発展 を大いに期待したい所である. も5少し広い立場からいって も, 相变態の時間的発展 (時間依存性) は最近の流れであるの で，そらいら意味でも今後の発展を大いに期待したい。

\section{4. マルテンサイトの時効効果}

$\mathrm{Au}-47.5$ 原子\% Cd 合金では, ゴム弾性的挙動と呼ばれる 奇妙な現象が1930年代に見出されているが(24)，その起源は 未解決である.この現象は, M 変態後直ちに変形すると, 応力を除荷しても变形したままであるが， $\mathrm{M}$ 相状態で適当 な時間時効すると, 時効とともに降伏応力は上昇し, 応力を 除荷するだけで元の形に戻ってしまらゴムのよらな性質であ る. 応力-歪曲線から見ると超弾性と酷似しているが, 母相一 $\mathrm{M}$ 相関の変態が関与せず，純粋に $\mathrm{M}$ 相内で起こる現象であ るといら点で, 超弾性とは全く異なる現象である. その後 In-Tl, $\mathrm{Cu}-\mathrm{Au}-\mathrm{Zn}, \mathrm{Cu}-\mathrm{Zn}-\mathrm{Al}, \mathrm{Cu}-\mathrm{Al}-\mathrm{Ni}, \mathrm{Au}-49.5$ 原子\%Cd ど多くの形状記憶合金でも見出されて扣り，かなり多くの形 状記憶合金に共通する一般的現象と考兄られる。またこれら の合金では $\mathrm{M}$ 相での時効に伴って $A s$ 点(逆変態開始温度) や $A f$ 点(同終了温度) も上昇する時効効果がみられるが，そ れらの時定数が注涪同じであることから二つの現象は同根と 考光られる. $\mathrm{M}$ 相での時効効果は，形状記憶合金の応用の 
際アクチュエータの動作点を変化させるので, 応用上も重要 な問題である. 時効飞伴う諎種の物性的性質の变化の中で特 に重要なるのだけ挙げれば以下の通りである(25).(i)時効に 伴って降伏応力は顕著に上昇する. (ii)時効効果の速さから見 て, 拡散(恐らく短範囲の) が強く関与している. (iii)時効に伴 って平均構造の変化はない。この奇妙な現象に対し, これ迄 多くの機構が提唱されたが，実験で得られた上記特徽などと 照らし合わせると，それらの殆どは消去され，それらの中で 最も可能性の高いと考兄られる機構は丸川-土谷 ${ }^{(26)}$ と上る “short range order(SRO) model” である. 彼らは具体的に $\mathrm{B} 2-\mathrm{L} 1_{0}$ 変態に対して具体的な解析を行っているが，その基 本的な考光方は以下の通りである. 母相の B2 相では, 一つ の原子の周りには 8 個の unlike nearest neighbors $(\mathrm{NN})$ が来 るが， $\mathrm{L} 1_{0}$ の $\mathrm{M}$ 相では $\mathrm{NN}$ の数が 12 個になるので, 変態の 際 4 個の like NN ができてしまら。このため M 相で, より 多くの unlike atoms の NNができるよう SRO が起こるとす るものである. 彼らのモデルにもいくつかの問題があるが, その中の重要な点は, SRO といいながら, このモデルでは long range order が壊れてしまらモデルであり，上記実験事 実の(iii)に抵触する可能性がある。これれ対し最近, 任(Ren) ら (27)は新しいモデルを提唱した。こちらも“SRO model” であるが，上記(iii)とは抵触しないモデルである。このモデル の骨子は以下の 3 点を基本とする.（i)この現象は不完全な 規則合金で起こる現象であり，焼入または構造的に導入され た格子欠陌[空孔および ASD (anti-structural defects)] 飞着 目する. (ii)平衡状態でのこれら格子欠陥の分布は $\mathrm{M}$ 相の対 称性飞従う。(iii)(ii) 飞基づくSRO のための拡散は同じ sub-lattice の中でだけで起こるとするものである.この考光によっ て, これ迄観察された実験結果をよく説明することができ, 特定の結晶構造によらない, 多くの形状記憶合金洪通の一 般的性質として説明することができる。しかし勿論どちらの モデルが正しいかは, 実験との撖密な比較によって決められ るべき問題であるが，とら遠くない将来に決着のつくことを 期待したい.

\section{Ti-Ni 合金薄膜}

実用的に広く使われている Ti-Ni 形状記憶合金に対して は，薄膜化してマイクロアクチュエータやマイクロマシーン に利用したいといら期待から，急冷凝固法を始め ${ }^{(28)}$, 種々 の薄膜作成が試みられ，今日ではマグネトロン・スパッター 法を用いて比較的容易に Ti-Ni 薄膜が得られるようになり, 組織拉よび機械的性質飞関して活発な研究が行われてい る(29)-(32). こうして得られた厚さ数 $\mu \mathrm{m}$ の薄膜の性質はバ ルク材と滦ぼ同じであるが, 薄膜の大きな特改は, アモルフ アス状態で下地の上堆積させた後結晶化処理をして試料薄 膜とするので, 結晶粒が極めて細かく, 機珹的性質の優れた 薄膜が作製できるといら点である。もら一つの特改はアモル ファス状態のため, 溶質原子を過飽和に固溶することがで
き，時効析出などの熱処理によって組織をコントロールでき

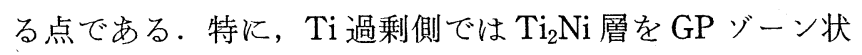
に析出させることによって, 機械的性質の非常に優れた薄膜 を作製することに関心が集まっている(33)(34)．また結晶化温 度より $50 \mathrm{~K}$ 程低温で加熱すると, $\phi 20 \sim 40 \mathrm{~nm}$ の同一方位 を持つ球状のナノ結晶集合体ができるといら興味深い報告も ある(35). こうして機械的特性瀀れた薄膜を作製するのは 既に可能になったが，実用化に向けての問題の一つは組成の 制御であるら，同一基盤上です組成は異なるようであるし， $\mathrm{Ti}-\mathrm{Ni}$ 合金の変態点は組成に対し極めて敏感であることを想 起すると, これからの大事な問題の一つと思われる. またマ イクロマシーンへの応用といらことになれば, 下地は当然 $\mathrm{Si}$ チップと思われるが, 両者の間の熱膨張係数の大きな相 違と下地からの拘束をどら回避するかる重要な問題である 5. 試験的な応用汇関して筆者が知るのは一例のみ(36)であ るが, 今後の発展のためには, 応用面での発展も大いに期待 したい。

\section{6. インテリジェント材料}

$M$ 変態の応用といら観点からすれば, 前項と並んで, イ ンテリジェント材料(またはスマート材料)の研究も活発であ る、インテリジェント材料の定義も狭義から広義迄種々ある が，ここではセンサー機能とアクチュエータ機能を持った材 料と簡単飞考兄ることにしょう。とすれば形状記憶合金 (SMA)は正に実在するインテリジェント材料他ならない。 特にこれ迄家電製品や自動車の一部として実用に供された形 状記憶合金アクチュェータはインテリジェント材の成功例と いらこともできる. 更に最近の傾向としては, SMA-ポリマ 一, SMA-TiC, SMA-金属といった複合材料がある. SMAポリマーは, SMA の逆変態を利用して, 弾性定数や剛性を 温度可変として, 航空機の振動制御に役立てょうと言うもの であり， SMA-TiC \& SMA に TiCを分散させて，弾性率を コントロールしょらとしたものである. 最後の Ti-Ni 線と $\mathrm{A} 1$ の複合材料は, プレストレス・コンクリートの原理で $\mathrm{Al}$ の強化を図ったものである ${ }^{(37)}$. 最近話題の高温形状記憶合 金もこの範疇に属するが，紙数の割合で割愛する.

\section{7. コンピュータ・シミュレーションによるマルテン サイト変態の研究}

computer simulation の利用は材料科学のあらゆる分野に 亘っていて, $M$ 変態も例外ではない. 特に $M$ 変態では二つ の流れがあるよ5に思われる。一つは $\mathrm{M}$ 変態が非常に速い 現象であるため, 核形成過程等原子レベルでの変態過程を実 験的に捉光るのは非常に困難である。このため molecular dynamicsを用いて, コンピュータ画面上で変態過程を見る ことによって研究しようといら立場である(38)(39). もら一つ はもら少しメゾスコピックレベルでの話であって, 非線型項 
を含む拡張した Ginzburg-Laudau 万程式をコンピュータで 解き, $\mathrm{M}$ 変態の時間的発展を解明しょうとするもので, 既 に 3 次元の解析も行われている ${ }^{(40)}$. 更に最近は, もら一つ の方向として，実験家が凡用の EAM(Embedded Atom Method) ソフトを利用して, 高分解能電顕, 電子回折などの 実験結果をコンピュータで再現しながら研究を進めていくと いう新しい方向も模索されている.

\section{8. ベーナイト変態}

ベーナイト変態は一般的に $\mathrm{M}$ 変態と拡散のからんだ問題 と考えられているが, 変態初期の核形成期に関して言えば, シアー説, 拡散説, 折覀説があって今以て決着はついていな いようである．従来シアー説の有力な根拠の一つとして表面 起伏の観察があったが，最近の atomic site correspondence ${ }^{(41)(42)}$ によれば表面起伏は, シアー過程の専売特許では なく，拡散型変態でも整合界面を持つ場合には，表面起伏は 現れらると考えられるよらになってきているので, 上記 3 説の区別は一層難しくなってきている.一方で, 測定法も進 歩し, 分析電顕のミクロ分析によれば, ベーナイト変態の初 期でも組成の変化が起きていることが明らかになってきてい るし ${ }^{(43)}$ ，電顕の干渉縞の観察からベーナイト変態に伴ら歪 の測定も可能になってきているので(44)，この基本的な問題 の解決されるのも遠くないことを期待したい. 本項の説明な らびに 4 項のマルテンサイト時効で述べたよらに，M変態 と拡散, あるいは $\mathrm{M}$ 変態と格子欠陥の係りのような, いわ ば他分野との境界に位置する問題が， $\mathrm{M}$ 変態研究において も一層重要になってくると思われる.

以上見てきたように，マルテンサイト変態の分野では, 現 在急速に進展しつつある問題, 現在発展の兆しが見えてきた 問題が多数ある. 特に今年の 4 月からは, 文部省科学研究 費補助金重点研究「相変態」もスタートしたし，1998年12 月にはアルゼンチンで “International Conference on Martensitic Transformations(ICOMAT-98)”が，1999年には京都 で "International Conference on Solid-Solid Phase Transformations”が本会主催(JIMIC-3)の下に開かれることが決ま っている．読者共々この分野の発展は大いに期待したい.

\section{文献}

（1）清水謙一：日本金属学会会報, 26 (1987), 605 .

(2) T. R. Finlayson and H. G. Smith: Met. Trans., 19A(1988), 193.

( 3 ) H. Abe, K. Oshima, T. Suzuki and S. Hoshino: Phys, Rev., 49B(1994), 3739.

(4) S. M. Shapiro, B. X. Yang, Y. Noda, L. E. Tanner and D. Schryvers: Phys. Rev., B44(1991), 9301.

( 5 ) T. Ohba, S. M. Shapiro, S. Aoki and K. Otsuka: Jpn. J. Appl. Phys., 33(1994), L1631.

(6) S. K. Satija, S. M. Shapiro, M. B. Salamon and C. M. Wayman: Phys. Rev., B29(1984), 6031.

( 7 ) S. Muto, R. Oshima and F. E. Fujita: Met. Trans., 19A(1988), 2931.
( 8 ) M. B. Salamon, M. E. Meichle and C. M. Wayman: Phys. Rev., 31B(1985), 7306.

（9）多見谷 隆, 板東義雄, 大塚和弘：日本金属学会春期大会講演 概要, (1995), p. 308.

(10) K. Otsuka: Materials Science Forum, 56-58(1990), 393.

(11) H. M. Ledbetter and C. M. Mayman: Acta Met., 20 (1972), 19.

(12) T. Tadaki, Y. Katano and K. Shimizu: Acta Met., 26(1978), 883.

(13) S. Aoki, K. Morii, Y. Murakami and K. Otsuka: Proc. Int. Conf. on Solid-Solid Phase Transformations (W. Johnson et al. ed.), Pittsburgh, (1994), p. 779

(14) K. M. Knowles and D. A. Smith: Acta Met., 29(1981), 101.

(15) T. Hara, T. Ohba, K. Otsuka, Y. Bando and S. Nenno: Proc. Int. Conf. on Martensitic Transformations (C. M. Wayman et al. ed.), (Monterey, 1993), p. 257.

(16) M. Nishida, K. Yamauchi, I. Itai, H. Ohgi and A. Chiba: Acta Met., 43(1995), 1229.

(17) Y. Kudo, M. Tokonami, S. Miyazaki and K. Otsuka: Acta Met., 33(1985), 2049.

(18) J. Ye, M. Tokonami and K. Otsuka: Met. Trans., 21A(1990), 2669.

(19) T. Ohba, Y. Emura and K. Otsuka: Mater. Trans., JIM, 33(1992), 29.

（20）中田芳幸, 唯木次男, 弘津禎彦：日本金属学会春期大会講演 概要, (1995), p. 308.

(21) T. Kakeshita, K. Kuroiwa, K. Shimizu, T. Ikeda, A. Yamagishi and M. Date: Mater. Trans., JIM, 34(1993), 423.

(22) H. Abe, M. Ishibashi, K. Ohshima and T. Suzuki: Phys. Rev., 50 (1994), 9020.

(23) T. Kakeshita, T. Fukuda and T. Saburi: Scripta Mater., 34(1996), 147.

(24) A. Ölander: J. Am. Chem. Soc., 56 (1932), 3819.

(25) Y. Murakami, Y. Nakajima, K. Otsuka, T. Ohba, R. Matuo and K. Ohshima: Materials Sci. \& Eng., A209 (1997), in press.

(26) K. Marukawa and K. Tsuchiya: Scripta Met. et Mater., 32 (1995), 77.

（27）任 暁兵, 石井友弥，大塚和弘：日本金属学会春期大会講演 概要, (1997), p. 81.

(28) Y. Furuya, M. Matsumoto, H. S. Kimura, K. Aoki and T. Masumoto: Mater. Trans., JIM, 31 (1990), 504.

(29) J. D. Busch, A. D. Johnson, C. H. Lee and D. A. Stevenson: J. Appl. Phys., 68(1990), 6224.

(30) S. Miyazaki, A. Ishida and A. Takei: Proc. Int. Conf. on Martensitic Transformations, (Monterey, 1993), p. 893.

(31) S. Miyazaki and A. Ishida: Mater. Trans., JIM, 35 (1994), 14.

(32) Y. Kawamura, A. Gyobu, H. Horikawa and T. Saburi: J. de Phys., Colloque N, C8, 5(1995), 683.

(33) Y. Nakata, T. Tadaki, H. Sakamoto, A. Tanaka and K. Shimizu: J. de Phys., Colloque N, C8, 5(1995), 671.

(34) S. Kajiwara, T. Kikuchi, K. Ogawa and T. Matsunaga: Phil. Mag. Lett., 74(1996), 137.

(35) S. Kajiwara, K. Ogawa, T. Kikuchi, T. Matsunaga and S. Miyazaki: Phil. Mag. Lett., 74(1996), 395.

(36) W. Benard, H. Kahn, M. A. Huff and A. H. Heuer: MRS Proc. (Boston, 1996), in press.

(37) Y. Furuya, A. Sasaki and M. Taya: Mater. Trans., JIM, 34(1993), 224.

(38) P. C. Clapp, Y. Shao and J. A. Rifkin: MRS Proc., 246(1992), 3.

(39) T. Tonokawa, T. Fukushima and T. Suzuki: Mater. Trans., JIM, 37 (1996), 1298.

(40) Y. Wang and A. G. Khachaturyan: Acta Mater., 45(1997), 759.

(41) J. M. Howe: Met. \& Mater. Trans., 25A(1994), 1917.

(42) T. Furuhara, K. Wada and T. Maki: Met. \& Mater. Trans., 26A (1995), 1971.

(43) T. Tadaki, C. J. Qiang and K. Shimizu: Mater. Trans., JIM, 32 (1991), 757

(44) K. Marukawa: Phil. Mag., 70A(1994), 35. 